\title{
KAJIAN HUKUM TERHADAP PELAKSANAAN PUTUSAN BADAN PENYELESAIAN SENGKETA KONSUMEN (BPSK) DI PENGADILAN NEGERI
}

\author{
Irvan Adi Putranto \\ Magister Ilmu Hukum, Fakultas Hukum, Universitas Diponegoro \\ Jl. Imam Barjo S.H. No. 5, Pleburan, Semarang Selatan, Pleburan, Kota Semarang, Jawa \\ Tengah 50241, Telp: (024) 8318856 \\ putrantoa93@gmail.com
}

\begin{abstract}
The Dispute Settlement Agency or better known as BPSK is the body in charge of handling and resolving disputes between business actors and consumers. initially consumers who feel aggrieved can only claim their rights by filing a lawsuit only through the Court, but with the birth of a consumer protection law, consumers who feel aggrieved can file a lawsuit at BPSK. The consumer dispute settlement process through BPSK adheres to the decision principle as final and binding, but the BPSK decision which is final and binding can still be made a legal effort to object to the parties who reject or object to the BPSK decision. The decision of BPSK cannot carry out its own decision therefore the execution of the BPSK decision is carried out by the District Court.
\end{abstract}

Keywords: Execution; Decision of BPSK; District Court

\begin{abstract}
Abstrak
Badan Penyelesaian Sengketa atau lebih dikenal dengan BPSK adalah badan yang bertugas menangani dan menyelesaikan sengketa antara pelaku usaha dan konsumen. pada awalnya konsumen yang merasa dirugikan hanya dapat menuntut hak-haknya dengan mengajukan gugatan melalui Pengadilan saja, namun dengan lahirnya undang-undang perlindungan konsumen, konsumen yang merasa dirugikan dapat mengajukan gugatan di BPSK. Proses penyelesaian sengketa konsumen melalui BPSK menganut prinsip putusan bersifat final dan mengikat, akan tetapi putusan BPSK yang bersifat final dan mengikat masih dapat dilakukan upaya hukum keberatan bagi para pihak yang menolak atau keberatan atas putusan BPSK. Putusan BPSK tidak dapat melaksanakan sendiri putusannya oleh karena itu eksekusi putusan BPSK dilakukan oleh Pengadilan Negeri.
\end{abstract}

Kata kunci : Eksekusi; Putusan BPSK; Pengadilan Negeri

\section{A. Pendahuluan}

Untuk menjamin suatu penyelenggaraan perlindungan konsumen, maka pemerintah menuangkan perlindungan dalam bentuk suatu produk hukum yaitu Undang-Undang Republik Indonesia Nomor 8 Tahun 1999 tentang perlindungan konsumen selanjutnya disebut UUPK. Hal ini sangatlah penting karena dengan adanya undang-undang perlindungan konsumen maka memaksa pelaku usaha menaati dan terdapat sanksi yang tegas.

Berdasarkan ketentuan Pasal 1 angka (1) UUPK dinyatakan bahwa perlindungan konsumen adalah segala upaya yang menjamin adanya kepastian hukum untuk memberikan perlindungan kepada konsumen.

Untuk mencegah pelaku usaha berbuat semena-mena, undang-undang Nomor 8 Tahun 1999 tentang Perlindungan 
Konsumen telah memberikan ruang bagi konsumen untuk menuntut hak-haknya.

Pasal 45 Ayat (1) Undang-Undang Nomor 8 Tahun 1999 tentang Perlindungan Konsumen menyebutkan setiap konsumen yang dirugikan bisa menggugat pelaku usaha melalui lembaga yang bertugas menyelesaikan sengketa antara konsumen dan pelaku atau melalui peradilan yang berada dilingkungan peradilan umum.

Sesuai dengan ketentuan Pasal 45 ayat (1) dan (2) UUPK disebutkan bahwa setiap konsumen yang dirugikan dapat menggugat pelaku usaha melalui lembaga yang bertugas menyelesaikan sengketa antara konsumen dan pelaku usaha atau melalui peradilan yang berada dilingkungan peradilan umum. Penyelesaian sengketa konsumen dapat ditempuh melalui pengadilan atau diluar pengadilan berdasarkan pilihan sukarela para pihak yang bersengketa.

Pada awalnya konsumen yang merasa dirugikan hanya dapat menuntut hakhaknya tersebut yaitu konsumen hanya bisa mengajukan gugatannya melalui pengadilan saja, namun dengan lahirnya undang-undang perlindungan konsumen sekarang ini, konsumen yang merasa dirugikan dapat menuntut kepada suatu lembaga yang berbentuk sebagai Badan Penyelesaian Sengketa Konsumen atau lebih dikenal dengan BPSK.

Badan Penyelesaian Sengketa Konsumen atau lebih dikenal dengan BPSK adalah badan yang bertugas menangani dan menyelesaikan sengketa antara pelaku usaha dan konsumen. BPSK dibentuk oleh pemerintah di daerah tingkat II ( kabupaten/kota) untuk penyelesaian sengketa konsumen diluar pengadilan, maka putusan BPSK bersifat final dan mengikat, tanpa upaya banding dan kasasi. (Zulham, 2014)

Berdasarkan pemaparan permasalahan di atas, maka penulis tertarik untuk menarik rumusan masalah yaitu, 1. Bagaimana akibat hukum terhadap putusan Badan Penyelesaian Sengketa Konsumen (BPSK) yang tidak didaftarkan di Pengadilan
Negeri setempat ? 2. Bagaimana prosedur untuk pengajuan pelaksanan eksekusi putusan Badan Penyelesaian Sengketa Konsumen (BPSK) ?

\section{B. Hasil dan Pembahasan}

1. Akibat Hukum Terhadap Putusan Badan Penyelesaian Sengketa Konsumen (BPSK) Yang Tidak Didaftarkan Di Pengadilan Negeri Setempat

Penyelesaian sengketa konsumen dilakukan dengan tiga cara yaitu konsiliasi, mediasi dan arbitrase. Didalam Pasal 4 dan 2 Surat Keputusan Menteri Perindustrian dan Perdagangan Nomor 350/MPP/Kep/12/2001 Ketiga cara penyelesaian sengketa tersebut dilakukan atas dasar pilihan dan persetujuan para pihak dan bukan proses penyelesaian sengketa secara berjenjang. Penyelesaian dengan cara konsiliasi ditempuh atas inisiatif salah satu pihak atau para pihak, sedangkan Majelis BPSK bersifat pasif, Majelis BPSK bertugas sebagai pementara antara pihak yang bersengketa. Penyelesaian secara mediasi ditempuh atas inisiatif salah satu pihak atau para pihak bedanya dengan konsiliasi, pada mediasi Majelis BPSK bersifat aktif sebagai pementara. Sedangkan penyelesaian secara arbitrase para pihak menyerahkan sepenuhnya kepada Majelis BPSK untuk memiutus dan menyelesaikan sengketa konsumen yang terjadi. (Shofie, 2008)

Tindakan eksekusi atau pelaksanaan putusan arbitase adalah suatu tindakan hukum yang dilakukan secara paksa terhadap pihak yang kalah dalam penyelesaian sengketa melalui lembaga arbitase. Biasanya tindakan eksekusi ini terjadi apabila dalam sengketa pihak Tergugat atau Termohon yang menjadi pihak yang kalah tidak bersedia melaksanakan putusan, sehingga kedudukannya menjadi pihak Tereksekusi. Putusan yang dapat dieksekusi adalah putusan yang memperoleh kekuatan hukum tetap, karena didalam putusan yang telah mempunyai kekuatan hukum tetap telah 
terkandung wujud hubungan hukum yang tetap dan pasti diantara pihak-pihak yang berpekara. Putusan arbitrase baru dapat dilaksanakan setelah salinan putusan resminya didaftarkan di Kepaniteraan Pengadilan Negeri dimana sengketa terjadi. Pasal 59 Undang-undang Nomor 30 Tahun 1999 pada ayat (1) menyatakan bahwa dalam waktu paling lama 30 (tiga puluh) hari terhitung sejak tanggal putusan diucapkan, lembaran asli atau salinan otentik putusan arbitrase diserahkan dan didaftarkan oleh arbiter atau kuasanya kepada Panitera Pengadilan Negeri, ketentuan ini menjadi wajib dilakukan karena apabila dilalaikan akan berakibat putusan tidak dapat dilaksanakan sebagaimana ditentukan dalam ayat (4) bahwa tidak dipenuhinya ketentuan dimaksud dalam ayat (1) berakibat putusan arbitrase tidak dapat dilaksanakan. Meskipun aturan hukumnya tidak melarang adanya pendaftaran secara lisan atau tertulis, akan tetapi demi kepastian dan ketelitian pengelola administrasi pengadilan negeri dan lembaga arbitrase sendiri, sebaiknya segala bentuk kegiatan dalam pendaftaran dilakukan secara tertulis, sehingga memudahkan didalam pertanggungjawaban masing-masing petugas apabila dilakukan suatu pemeriksaan perkara. Selanjutnya permohoman pendaftaran harus diajukan kepada Panitera Pengadilan Negeri dan Panitera bersama-sama dengan arbiter atau kuasanya harus membuat dan menandatangani akta pendaftaran putusan arbitrase. Bentuk akta pendaftaran bukan merupakan akta yang terpisah melainkan berupa pencatatan dan penandatanganan pada bagian akhir atau pinggir halaman putusan sehingga putusan tersebut menjadi autentik dan dapat dijalankan sebagaimana menjalankan putusan perdata Pengadilan Negeri yang telah mempunyai kekuatan hukum tetap. Praktik di Indonesia yang dilakukan oleh para arbiter BANI ternyata sedikit berbeda dengan apa yang diatur dalam Undang-Undang Nomor 30 Tahun 1999 yang mewajibkan kepada arbiter atau kuasanya segera mendaftarkan putusannya ke Pengadilan Negeri. Menurut aturan yang dijadikan pedoman BANI, arbiter atau majelis arbitrase bisa memberikan hak kepada para pihak untuk melaksanakan putusan secara sukarela dalam tenggang waktu yang ditentukan sebelum masa 30 hari untuk pendaftaran putusan, apabila sudah menjelang tenggang waktu yang ditentukan para pihak ternyata tidak melaksanakan secara sukarela, maka barulah putusan tersebut diserahkan kepada Pengadilan Negeri untuk dilakukan pendaftaran sesuai prosedur yang berlaku. Selanjutnya Ketua Pengadilan Negeri akan mendaftar dan memfiat eksekusi putusan tersebut dengan suatu putusan pengadilan dengan cara memuat suatu catatan di kepala putusan arbitrase yang berbunyi "Demi Keadilan Berdasarkan Ketuhanan Yang Maha Esa". Dengan fiat eksekusi seperti ini, putusan arbitrase tersebut sudah dapat dijalankan sebagaimana menjalankan putusan Pengadilan Negeri. (Sutiarso, 2011)

Pengajuan keberatan atas Putusan BPSK diajukan dalam bentuk gugatan (bukan Vountair) sebagaimana diatur dalam Peraturan Mahlkamah Agung RI Nomor 01 Tahun 2006. Keberatan diajukan dalam tenggang waktu 14 hari sejak pelaku usaha atau konsumen menerima pemberitahuan putusan BPSK. Keberatan diajukan melalui kepaniteraan Pengadilan Negeri tempat kedudukan hukum Pelaku Usaha atau Konsumen. Upaya hukum terhadap putusan keberatan atas putusan BPSK adalah kasasi. (Pedoman Teknis Administrasi dan Teknis Peradilan Perdata Umum dan Perdata Khusus, 2007)

\section{Prosedur Untuk Pengajuan \\ Pelaksanan Eksekusi Putusan Badan Penyelesaian Sengketa Konsumen (BPSK)}

Menurut ketentuan Pasal 54 ayat (4)

jo. Pasal 26 sampai Pasal 36 Kepmenperindag No. 350/MPP/12/2001 bentuk penyelesaian perkara di Badan Penyelesaian Konsumen dapat 
diselesaiakan dengan 3 cara yaitu Konsiliasi, Mediasi, Arbitase.

Penyelesaian sengketa konsumen dengan cara Konsiliasi dilakukakan sendiri oleh para pihak yang bersengketa dengan didampingi oleh Majelis yang bertindak pasif sebagai Konsiliator sedangkan penyelesaian sengketa konsumen dengan cara Mediasi dilakukan sendiri oleh para pihak yang bersengketa dengan didampingi oleh Majelis yang bertindak aktif sebagi Mediator. Akan tetapi penyelesaian sengketa konsumen dengan cara Arbitrase dilakukan sepenuhnya dan diputus oleh Majelis yang bertindak sebagai Arbiter.

Penyelesaian sengketa konsumen dengan cara Konsiliasi dan Mediasi dilakukan dalam bentuk kesepakatan yang dibuat dalam perjanjian tertulis yang kemudian ditandatangani oleh para pihak yang bersengketa dan dituangkan dalam perjanjian tertulis kemudian dikuatkan dalam bentuk keputusan BPSK.

Pada persidangan dengan cara arbitrase, para pihak yang bersengketa menyerahkan sepenuhnya penyelesaian sengketa konsumen kepada Majelis BPSK untuk memutus dan menyelesaikan sengketa tersebut. Proses pemilihan Majelis BPSK menurut ketentuan Pasal 32 Kepmenperindag No. 350/MPP/12/2001 dengan cara arbitrase dapat melalui 2 cara yaitu: pertama, para pihak memilih arbitor dari anggota BPSK yang berasal dari unsur pelaku usaha dan konsumen sebagai anggota BPSK. Kedua, arbitor yang dipilih para pihak tersebut kemudian memilih arbitor ketiga dari anggota BPSK sedangkan arbitor dari unsur pemerintah selalu dipilih untuk menjadi Ketua Majelis.

Bentuk Putusan Badan Penyelesaian Sengketa Konsumen yang diselesaikan dengan cara arbitrase dapat berupa Perdamaian, Gugatan ditolak, Gugatan dikabulkan.

Berdasarkan Pasal 38

Kepmenperindag No.350/MPP/12/2001 Majelis wajib memutuskan sengketa konsumen tersebut selambat-lambatnya dalam waktu 21 hari kerja terhitung sejak gugatan diterima BPSK. Setelah putusan BPSK diberitahukan selambat-lambatnya dalam 7 hari kerja sejak putusan dibacakan, konsumen dan pelaku usaha yang bersengketa wajib menyatakan menerima atau menolak putusan BPSK tersebut.

Apabila konsumen dan pelaku usaha menolak putusan BPSK, maka mereka dapat mengajukan keberatan kepada Pengadilan Negeri selambat-lambatnya dalam waktu 14 hari kerja terhitung sejak putusan BPSK diberitahukan.

Sebaliknya apabila konsumen dan pelaku usaha menerima putusan tersebut maka pelaku usaha wajib menjalankan putusan tersebut selambat-lambatnya dalam waktu 7 hari kerja sejak dinyatakan menerima putusan tersebut.

Putusan BPSK yang tidak diajukan keberatan oleh Pelaku Usaha, dimintakan penetapan fiat eksekusi kepada Pengadilan Negeri di tempat tinggal konsumen yang dirugikan.

Mengenai prosedur eksekusi perkara perdata:

Bahwa terhadap proses pelaksanaan eksekusi perkara perdata ada beberapa hal yang harus menjadi perhatian bagi petugas yang diberi tanggung jawab untuk menerima permohonan eksekusi sebelum eksekusi tersebut diterima di bagian Kepaniteraan Perdata. Hal-hal tersebut yaitu:

a. Diperiksa terlebih dahulu apakah perkara yang dimohonkan eksekusi tersebut telah berkekuatan hukum tetap (BHT) atau belum.

Untuk melihat perkara tersebut sudah berkekuatan hukum tetap apa belum dapat dilihat dari relaas pemberitahuan putusan yang telah disampaikan oleh Juru Sita kepada para pihak apakah sudah melewati tenggang waktu 14 hari apa belom. Apabila pihak tergugatnya banyak maka yang dijadikan patokan untuk menghitung putusan tersebut telah berkekuatan hukum tetap adalah dihitung dari para pihak tergugat yang di panggil terakhir sekali. 
b. Kemudian selain itu agar perkara perdata bisa di eksekusi harus dilihat dulu apakah didalam putusan perdata tersebut ada amar condemnatoir atau amar yang menghukum pihak tergugat. Amar yang bersifat condemnatoir bisa berupa perintah membayar sejumlah uang, melakukan suatu perbuatan seperti mengosongkan, menghentikan, membongkar, menghentikan, membagi.

Apabila setelah dilihat putusan perdata yang akan dimohonkan eksekusi tersebut tidak terdapat comdemnatoir atau yang bersifat menghukum maka disampaikan kepada pemohon eksekusi untuk mengajukan gugatan baru dengan disertai putusan serta merta (Pasal 191 ayat (1) Rbg / 180 ayat (1) HIR.

Misalnya pada putusan yang sudah berkekuatan hukum tetap yang akan dimohonkan eksekusi tersebut hanya mencantumkan penggugat sebagai pemilik objek sengketa (deklaratoir) tanpa ada amar yang menghukum tergugat (comdemnatoir) untuk menyerahkan dan mengosongkan tanah obyek sengketa. Terhadap hal tersebut penggugat dapat mengajukan gugatan baru berdasarkan putusan tersebut mengenai penyerahan dan pengosongan objek sengketa oleh tergugat dan terhadap gugatan yang diajukan didasarkan atas putusan tadi, dapat dijatuhkan putusan eksekusi terlebih dahulu.

c. Apabila putusan perdata tersebut setelah dilihat dan diteliti sudah berkekuatan hukum tetap dan ada amar yang bersifat comdemnatoir maka kepada si pemohon eksekusi dapat melakukan pembayaran SKUM eksekusi setelah itu pemohonan eksekusi diajukan kepada Ketua Pengadilan Negeri dengan melampirkan putusan.

d. Kemudian permohonan tersebut dimasukan kedalam register eksekusi. e. Setelah selesai seluruh tahap-tahap tersebut maka tahap selanjutnya adalah persiapan Aanmaning.

Mengenai Prosedur Khusus untuk Permohonan Eksekusi putusan BPSK yang apabila putusan BPSK tidak diajukan upaya hukum keberatan dan putusan tersebut sudah berkekuatan hukum tetap, maka pada waktu mengajukan permohonan eksekusi pemohon harus melampirkan putusan BPSK yang sudah berkekuatan hukum tetap tersebut ke Pengadilan Negeri. Namun apabila terhadap putusan tersebut ada diajukan upaya hukum (keberatan/kasasi) maka putusan yang harus dilampirkan untuk pemohon eksekusi adalah putusan keberatan dari Pengadilan Negeri dan Putusan Kasasi dari Mahkamah Agung. Khusus untuk perkara BPSK yang sudah mempunyai kekuatan hukum tetap (karena tidak diajukan upaya hukum keberatan/kasasi), maka persyaratan yang harus dipenuhi adalah pemberitahuan putusan. Biasanya dalam praktek pihak BPSK/ Pemohon Eksekusi hanya melampirkan bukti pemberitahuan lewat surat (seperti resi surat lewat pos), kalau terjadi demikian maka bagian kepaniteraan perdata harus menyarankan kepada pihak BPSK untuk memberitahukan ulang dengan melalui kurir agar supaya ada bukti tertulis kapan secara nyata putusan itu diterima/disampaikan kepada pihak termohon eksekusi karena kalau pemberitahuan putusan BPSK hanya disampaikan lewat surat (via pos), pihak Pengadilan akan kesulitan untuk menentukan bahwa putusan BPSK tersebut telah berkekuatan hukum tetap atau belum karena untuk menentukan bahwa putusan tersebut telah berkekuatan hukum tetap terhitung sejak itu disampaikan atau diberitahukan kepada pihak termohon apakah pihak termohon masih akan mengajukan upaya hukum keberatan atau tidak terhadap putusan BPSK dalam tenggang waktu 14 hari kerja. Permasalahan lain yang dihadapi oleh Pengadilan Negeri khususnya terhadap 
permohonan eksekusi BPSK yaitu mengenai pihak yang mengajukan permohonan eksekusi terhadap putusan BPSK, sesuai dengan hukum acara BPSK (Kepmenperindag RI No. 350/MPP/Kep/12/2001) Pasal 42 ayat (2) yang mengajukan permohonan eksekusi adalah BPSK (selaku arbiter). Hal ini sangat bertentangan dengan Hukum Acara di Pengadilan (HIR/Rbg) dimana pihak yang berhak mengajukan eksekusi adalah pihak yang dimenangkan dalam perkara tersebut. Dalam praktek pihak BPSK dalam mengajukan permohonan eksekusi dengan melalui surat sehingga hal ini sangat menghambat dalam mewujudkan proses peradilan cepat karena Pengadilan Negeri harus menyurati pihak BPSK karena sesuai dengan Hukum Acara di Pengadilan yang berhak mengajukan eksekusi adalah pihak yang dimenangkan karena si Pemohon Ekesekusi harus membayar perkara eksekusi.

Pihak yang dapat mengajukan eksekusi ke Pengadilan Negeri ialah Pihak yang menang, kemudian pihak yang menang mengajukan Permohonan Eksekusi kepada Ketua Pengadilan negeri dan selanjutnya menemui Panitera Muda Perdata untuk menentukan besarnya Panjar Eksekusi yang disesuaikan dengan SK Radius yang ditetapkan Ketua Pengadilan Negeri (disesuaikan dengan jarak alamat dari Termohon Eksekusi yang dipanggil). Kemudian kalau sudah ditentukan biaya Panjar Perkara biaya eksekusi selanjutnya pihak Termohon Eksekusi diperintahkan untuk membayar Panjar biaya perkara eksekusi melalui Bank yang ditunjuk oleh Pengadilan Negeri yaitu Bank Mandiri. Selanjutnya pihak Pemohon menyerahkan bukti pembayaran Bank tersebut kepada kasir yang ada pada bagian perdata tersebut. Selanjutnya kasir akan memberikan tanda terima berupa SKUM (Surat Kuasa Untuk Membayar), lalu berkas perkara permohonan eksekusi yang diajukan oleh Pemohon tersebut akan dicatat dalam Register Ekseskusi. Setelah dicatat didalam register eksekusi selanjutnya berkas permohonan eksekusi yang diajukan oleh Pemohon tersebut akan diteruskan kepada Ketua Pengadilan Negeri untuk ditindaklanjuti.

Tahap Eksekusi BPSK:

a. Tahapan eksekusi BPSK dimulai dengan Aanmaning / peneguran terhadap termohon eksekusi agar mau melaksanakan putusan BPSK tersebut secara sukarela (dalam waktu 8 hari kerja terhitung sejak peneguran).

b. Untuk melakukan peneguran / Aanmaning terhadap Termohon eksekusi tersebut Ketua Pengadilan Negeri akan mengeluarkan produk penetapan Aanmaning yang isinya memerintahkan kepada Panitera atau jika berhalangan akan ditunjuk Juru Sita untuk melakukan pemanggilan terhadap Termohon Eksekusi pada hari dan tanggal yang telah ditetapkan Ketua Pengadilan Negeri.

c. Atas dasar penetapan Aanmaning yang dikeluarkan oleh Ketua Pengadilan Negeri tersebut maka Juru Sita akan mengeluarkan pemanggilan terhadap Termohon eksekusi pada hari dan tanggal yang ditetapkan oleh ketua Pengadilan Negeri tersebut.

Tahap Sita Eksekusi:

Dalam putusan BPSK yang terkait dengan sengketa konsumen dengan Pelaku Usaha apabila Pelaku Usaha dinyatakan terbukti bersalah (melanggar UU Perlindungan Konsumen No. 8 Tahun 1999), Biasanya BPSK dalam amar putusannya akan dihukum untuk membayar denda administratif yang besarnya maksimal hingga Rp. 200.000.000,- (dua ratus juta rupiah). Jadi apabila dalam putusan BPSK pihak Pelaku Usaha dihukum untuk membayar denda administratif maka dapat disimpulkan bahwa bentuk eksekusi adalah berupa penghukuman untuk pembayaran sejumlah uang (dihukum untuk membayar denda administratif) dan apabila sewaktu di Aanmaning Pelaku Usaha tersebut tidak mau membayar denda administratif tersebut dalam amar putusan BPSK maka 
langkah selanjutnya biasanya permohonan eksekusi akan mencari harta milik Termohon baik yang bergerak maupun yang tidak bergerak untuk dimohonkan sita eksekusi agar dapat di lelang dimuka umum guna memenuhi atau untuk membayar denda administratif sebagaimana yang disebutkan dalam amar putusan BPSK. Untuk melakukan sita eksekusi yang diperintahkan oleh Ketua Pengadilan Negeri tersebut maka Juru Sita akan mendatangi objek yang akan di Sita Eksekusi, yang mana seandainya benda yang akan di eksekusi tersebut berupa tanah maka Juru Sita harus mencatat luas tanah dan mencatat batas-batas dari tanah tersebut, selanjutnya dituangkan dalam berita acara eksekusi. Kalau tanah yang disita eksekusi tersebut sudah bersertifikat maka juru sita harus mendaftarkan sita eksekusi yang telah dilakukan tersebut di Kantor BPN (Badan Pertanahan Nasional) setempat untuk melakukan pemblokiran / mencatat tanah yang telah disita eksekusi oleh Juru Sita tersebut dalam register yang tersedia untuk itu, namun apabila tanah yang disita eksekusi tersebut belum bersetifikat maka Juru Sita akan mendaftarkan tanah yang telah disita eksekusi tersebut ke kantor desa / kantor kelurahan setempat. Terhadap tanah yang telah diletakan sita eksekusi tersebut tidak bisa dipindah tangankan, diperjual-belikan maupun dijaminkan. Apabila sudah sampai tahap sita eksekusi ternyata pihak termohon juga belum melaksanakan isi putusan tersebut secara sukarela maka tahap selanjutnya Pengadilan Negeri akan melakukan pelelangan terhadap obyek yang telah diletakan sita eksekusi tersebut yang akan dilakukan pelelangan secara umum.

Tahap Pelelangan Terhadap Objek Yang Telah Di Letakan Sita Eksekusi:

Untuk melakukan pelelangan objek yang telah disita eksekusi Pengadilan tidak bisa melakukan pelelangan sendiri, namun untuk melakukan pelelangan tersebut Pengadilan harus meminta bantuan kepada KPKLN (Kantor Pelayanan Kekayaan Negara dan Lelang).
Sebelum dilakukan pelelangan pihak Pengadilan selaku pihak Pemohon lelang harus menentukan harga limit. Untuk menentukan harga limit pihak Pengadilan biasanya minta bantuan kepada Appraisal / Juru Taksir. Beban biaya Appraisal / Juru Taksir dibebankan kepada pihak permohonan eksekusi.

Pihak Pengadilan untuk meminta bantuan pelelangan terhadap obyek yang telah disita eksekusi tersebut, Ketua Pengadilan Negeri harus mengajukan permohonan bantuan pelelangan secara tertulis yang ditunjukan kepada KPKNL, dengen melengkapi persyaratan antara lain berupa:
a. Penetapan lelang dari Ketua Pengadilan Negeri.
b. Penetapan harga limit.
c. Berita acara Aanmaning.
d. Surat keputusan penunjukan pejabat penjual barang.
e. Surat keterangan pendaftaran tanah dari BPN setempat.
Setelah permohonan bantuan lelang tersebut diajukan KPKNL maka selanjutnya pihak KPKLN akan menentukan hari dan tanggal pelelangan secara umum yang nantinya harus diumumkan sebanyak 2 kali yang akan dilakukan oleh Pengadilan Negeri yang mengajukan permohonan lelang tersebut.Dalam praktek pelelangan secara umum tersebut akan diumumkan sebanyak 2 kali pengumuman yang pertama bisa dilakukan melalui pengumuman lelang yang ditempat kantor Pengadilan Negeri dan Pemerintah Daerah (PEMDA) setempat. Sedangkan untuk pengumuman pelaksanaan lelang yang kedua harus diumumkan melalui surat kabar yang ada di daerah wilayah tersebut.

Apabila objek tanah yang dilelang tersebut telah terjual melalui lelang maka pihak pemenang lelang akan dibebani pajak $2 \%$ untuk pembeli dan 1,5\% untuk penjual (sesuai dengan ketentuan PP No. 1 Tahun 2013 tentang Penerimaan Negara Bukan Pajak atau PNBP). 
Hasil tanah lelang tersebut dikurangi $1,5 \%$ untuk penjual kemudian dikurangi hutang pihak pemohon selanjutnya apabila terdapat sisa maka sisanya tersebut di kembalikan kepada pihak termohon eksekusi. (Kaswanto, 2018)

\section{Simpulan}

1. Pengaturan permohonan eksekusi BPSK yang mengajukan adalah BPSK sendiri selaku arbiter mengacu pada hukum acara BPSK Kepmenperindag RI No 350/MPP/Kep/12/2001 sedangkan hukum acara di Pengadilan Negeri HIR/Rbg dimana pihak yang berhak mengajukan eksekusi adalah pihak yang dimenangkan dalam perkara tersebut karena yang membayar biaya permohonan eksekusi. Di masa yang akan datang harus memberikan perhatian terkait mekanisme pengajuan permohonan eksekusi agar tidak terjadi perbedaan dalam menentukan siapa yang mengajukan permohonan eksekusi dan melakukan pendaftaran eksekusi.

2. Mengenai pemberitahuan putusan BPSK yang disampaikan melalui kurir BPSK kepada Termohon namun kurir BPSK tidak bertemu secara langsung dengan si Termohon (misal kantor Termohon tutup), hal ini pun akan menimbulkan permasalahan hukum apakah kurir mempunyai kewenangan untuk memberitahukan Putusan BPSK tersebut melalui kantor kepala desa atau kantor Kelurahan dan terhadap hal tersebut. Bahwa pihak BPSK dapat meminta bantuan kepada Pengadilan Negeri untuk memberitahukan putusan tersebut sehingga nanti Juru sita Pengadilan Negeri akan memberitahukan putusan tersebut melalui kepala Desa atau Lurah dan panggilan tersebut adalah sah.

\section{DAFTAR PUSTAKA}

\section{Buku}

Shofie Yusuf. 2008. Kapita Selekta Hukum Perlindungan Konsumen Di Indonesia. Bandung: PT Citra Aditya Bakti

Sutiarso Cicut 2011. Pelaksanaan Putusan Arbitrase Dalam Sengketa Bisnis. Jakarta: Yayasan Pustaka Obor Indonesia

Zulham. 2013. Hukum Perlindungan Konsumen. Kencana Media Group.

\section{Peraturan Perundang-undangan}

Undang-Undang Republik Indonesia Nomor 8 Tahun 1999 tentang Perlindungan Konsumen

Undang-Undang Republik Indonesia Nomor 30 Tahun 1999 Tentang Arbitrase dan Alternatif Penyelesaian Sengketa

Keputusan Menteri Perindustrian Dan Perdagangan Nomor 350/Mpp/Kep/12/2001 Tahun 2001 Tentang Pelaksanaan Tugas Dan Wewenang Badan Penyelesaian Sengketa Konsumen

Peraturan Mahkamah Agung Nomor 1 Tahun 2006 Tentang Tata Cara Pengajuan Keberatan Terhadap Putusan Badan Penyelesaian Sengketa Konsumen

Pedoman Teknis Administrasi Dan Teknis Peradilan Perdata Buku II Edisi 2007, Mahkamah Agung 2008

\section{Wawancara}

Kaswanto, Pengajuan Eksekusi Putusan BPSK Di Pengadilan Negeri, Jabatan sebagai Ketua Pengadilan Negeri Lubuklinggau, Pengadilan Negeri Lubuklinggau, Pukul 10.00 WIB tanggal 02 Juli 2015. 